\title{
Description of a new species of Odontochrydium Brauns (Hymenoptera: Chrysididae) from the Arabian Peninsula
}

\author{
AHMED M. SOLIMAN ${ }^{1,3 *}$, PAOLO ROSA ${ }^{4} \&$ HATHAL M. AL DHAFER ${ }^{1,2}$ \\ ${ }^{1}$ Plant Protection Department, College of Food and Agriculture Sciences, King Saud University, P.O. BOX 2460, Riyadh 11451, Saudi \\ Arabia \\ ${ }^{2} \equiv "$ hdhafer@ksu.edu.sa; 1 https://orcid.org/0000-0002-4911-2332 \\ ${ }^{3}$ Zoology Department, Faculty of Science (Boys), Al-Azhar University, P.O. Box 11884, Nasr City, Cairo, Egypt \\ ${ }^{4}$ Université de Mons, Laboratoire de Zoologie, Place du parc 20, 7000 Mons, Belgium. \\ ”-paolo.rosa@umons.ac.be; † https://orcid.org/0000-0003-2919-5297 \\ "Corresponding author "amsoliman@ksu.edu.sa; ”ammsoliman@gmail.com; @ http://orcid.org/0000-0001-5284-713
}

\begin{abstract}
Odontochrydium arabicum sp. nov., a new chrysidid species from Oman, southwestern Saudi Arabia, and Yemen is described, illustrated and compared with the African species, O. bicristatum Rosa from Kenya.
\end{abstract}

Key words: Afrotropical, male genitalia, new species, Oman, Saudi Arabia, Yemen

\section{Introduction}

Odontochrydium Brauns, 1928 is a small chrysidid genus including only three species so far: O. irregulare (Mocsáry, 1914) (synonym: O. trautmanni Brauns, 1928), widely distributed in sub-Saharan Africa (Angola, Democratic Republic of Congo, Kenya, Malawi, Namibia, South Africa, Uganda, Zimbabwe), O. bicristatum Rosa, 2018, known from Kenya, and O. xuii Rosa, 2018, known from southern India (Kimsey \& Bohart 1991; Madl \& Rosa 2012; Rosa 2018).

The occurrence of Odontochrydium in the Arabian Peninsula has been recorded only recently, based on a single female specimen collected in Asir region of Saudi Arabia (Rosa 2018; Rosa et al. 2020). This specimen was doubtfully considered as the female of $O$. bicristatum for the bicrestate median lobe of mesoscutum and the large and scattered metasomal punctation. However, the examination of male specimens from Saudi Arabia was considered necessary for the correct identification of this specimen.

The recent finding of males from Saudi Arabia and Oman, and further females from Oman, Saudi Arabia and Yemen, clarifies the taxonomic position of this taxon and allows the description as a new species which is so far limited to the Arabian Peninsula.

\section{Material and methods}

The present study is based on Odontochrydium specimens collected from the south of the Arabian Peninsula, Oman, Asir and Jazan regions in Saudi Arabia, Yemen (Fig. 6) and Kenya (Africa) using sweep net and Malaise trap. Specimens were examined and described using a MEIJI-EMZ-10 stereomicroscope with magnification up to $180 \times$ and a Carton Togal stereomicroscope, fitted with an ocular micrometer for measurements. The male genitalia of the new species was extracted and left in cold $10 \% \mathrm{NaOH}$ solution for $24 \mathrm{~h}$, before being washed with distilled water and then with an ascending series of ethyl alcohol (70\%-100\%), and finally submerged in glycerol on a concave slide for photographing.

Photographs were taken with a Canon EOS 70D camera attached to a LEICA MZ-125 stereomicroscope and a 
Camera Olympus E-M1 Mark II with the Olympus Zuiko 60mm objective and stacked with the software Helicon Focus (ver. 7.6). Further image processing was completed with Adobe Photoshop CS5.1 (ver. 12.1.0.0) and Adobe Photoshop Lightroom $5.2 \times 64$ (ver. 5.2.0.10) software programs.

Morphological terminology follows Kimsey \& Bohart (1991). The terminology adopted for wing cells and veins follows Goulet \& Huber (1993). Body sculpture terminology follows Harris (1979). The abbreviations are as follows: AOD = anterior ocellus diameter; F1, F2, F3, etc. = first, second, third, etc. antennal flagellomeres; MS = malar space, the shortest distance between the base of the mandible and the ventral margin of the eye; OOL $=$ distance between posterior ocellus and inner eye margin; $\mathbf{P}=$ Pedicel; $\mathbf{P O L}=$ the shortest distance between posterior ocelli; S1, S2, S3, etc. $=$ first, second, third, etc. metasomal sterna; $\mathbf{T 1}, \mathbf{T 2}, \mathbf{T 3}$, etc. $=$ first, second, third, etc. metasomal terga; $\mathbf{T F C}=$ transverse frontal carina. Forewing cells and veins: $\mathbf{2 R \mathbf { 1 }}=$ second radial 1 cell; $\mathbf{R}=$ radial cell; $\mathbf{M}=$ median vein; $\mathbf{M}+\mathbf{C u}=$ median + cubital vein; $\mathbf{c u - a}=$ cubitoanal cross-vein .

The material belongs to the following depositories: FSPC — Franco Strumia private collection, Pisa (Italy); KSMA - King Saud University Museum of Arthropods (Plant Protection Department, College of Food and Agriculture Sciences, King Saud University, Riyadh, Saudi Arabia); MHPC—Marek Halada private collection, České Budějovice (Czech Republic); PRPC - Paolo Rosa private collection, Bernareggio (Italy), and RMNH-Naturalis Biodiversity Center, Leiden (The Netherlands).

\section{Results}

Odontochrydium arabicum Soliman \& Rosa, sp. nov.

Figures 1-4

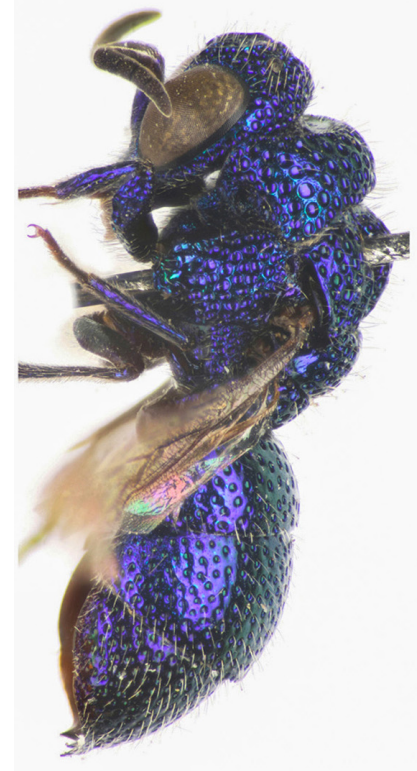

A
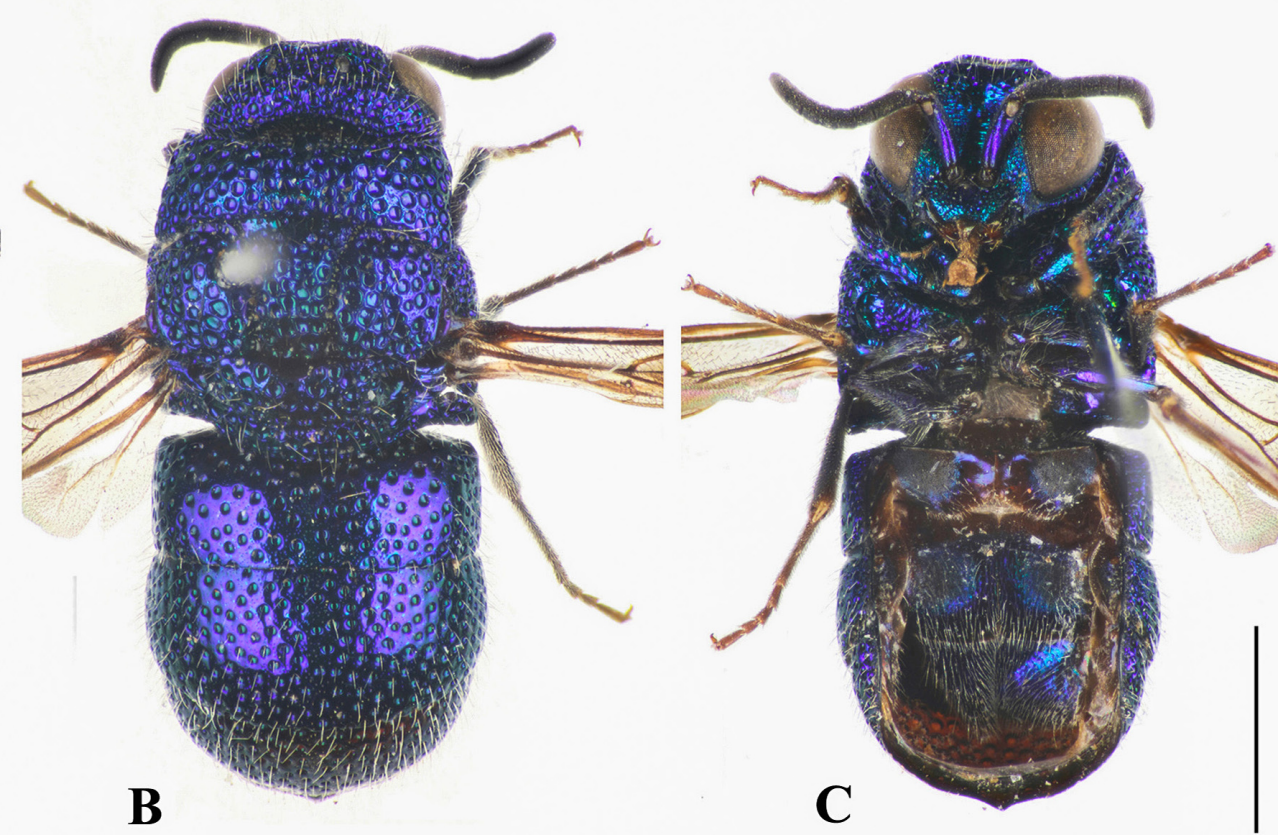

FIGURE 1A-C. Odontochrydium arabicum sp. nov., male, holotype. A. Habitus, lateral view; B. Habitus, dorsal view; C. Habitus, ventral view. Scale $=1.0 \mathrm{~mm}$.

Type materials. Holotype ${ }^{\lambda}$, Saudi Arabia: Asir region, Abha, Wadi Mashwas $\left[18^{\circ} 10^{\prime} 06^{\prime \prime} \mathrm{N} 42^{\circ} 22^{\prime} 04^{\prime \prime} \mathrm{E}\right.$, Alt. $1251 \mathrm{~m}], 20 . X I .2015$, leg. Ahmed M. Soliman, sweep net [KSMA]. Paratypes: 1 , Oman: Dhofar, Wadi Magsail

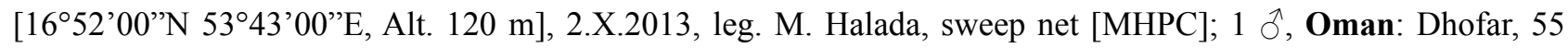

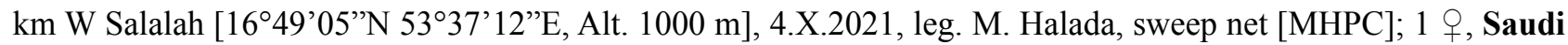
Arabia: Asir region, Marabah, Al-Hudaithy farm [17 $50^{\prime} 53^{\prime \prime} \mathrm{N} 42^{\circ} 23^{\prime} 11^{\prime \prime} \mathrm{E}$, Alt. $226 \mathrm{~m}$ ], 9.III.2015, leg. Hasan

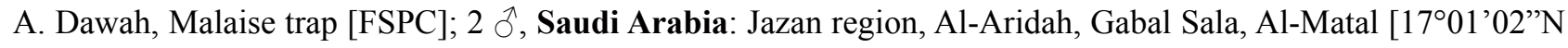
4307’01'”E, Alt. 290 m], 9.I.2022, leg. Ahmed M. Soliman, sweep net [KSMA, PRPC]; 1 +, Saudi Arabia: Jazan

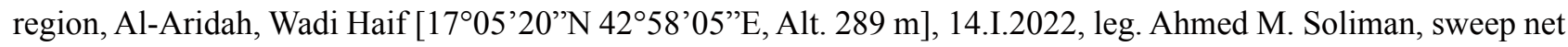
[KSMA]; 1 +, Yemen: Al Lahima, 16.X-31.XII.2000, leg. A.v. Harten \& A.M. Hager, Malaise trap / RMNH Leiden 
ex collection ZMAN [RMNH]; 1 q, Yemen: Al Lahima, 9.IV-5.VI.2001, leg. A.v. Harten, Malaise trap [RMNH];

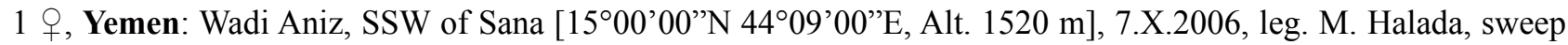
net [MHPC].

Diagnosis. Body metallic dark blue, with violet and greenish reflections (Figs 1, 4); mesoscutal median area reticulate-foveate, with two stout longitudinal ridges forming elongate fovea between ridges (Figs 2E, 4C); metasomal tergites sparsely, largely punctate (Figs 1B, 3C, 4C, D); T3 apico-median tooth longer to distinctly longer than lateral ones (Figs 3C, 4D); S1 and S2 with pair of widely separated black spots, adjacent to lateral margin of sternites (Fig. 3D).
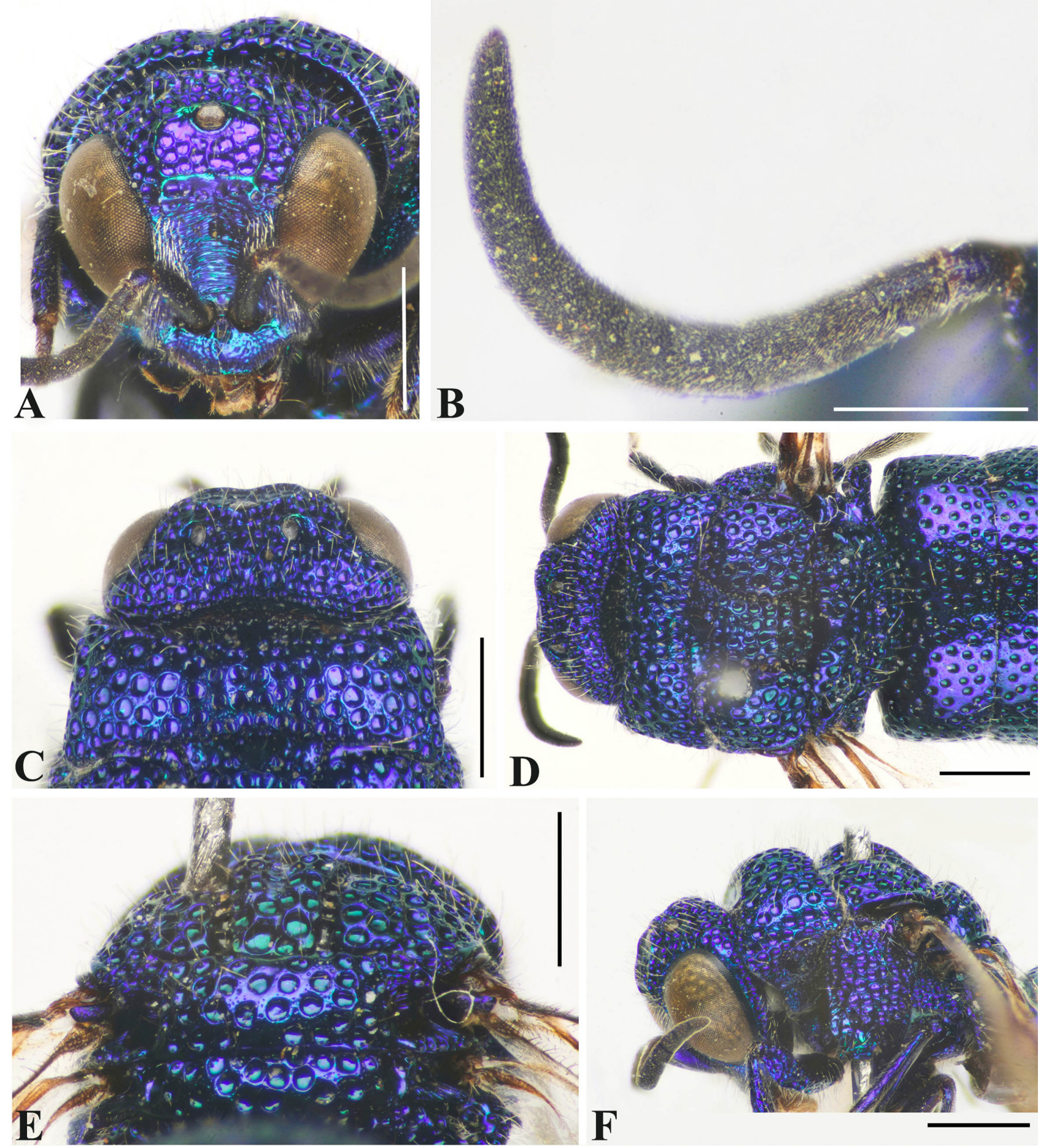

FIGURE 2A-F. Odontochrydium arabicum sp. nov., male, holotype. A. Head, frontal view; B. Antenna; C. Head and pronotum, dorsal view; D. Head, mesosoma and T1, dorsal view; E. Mesosoma, detail; F. Head and mesosoma, lateral view. Scales $=0.5 \mathrm{~mm}$. 

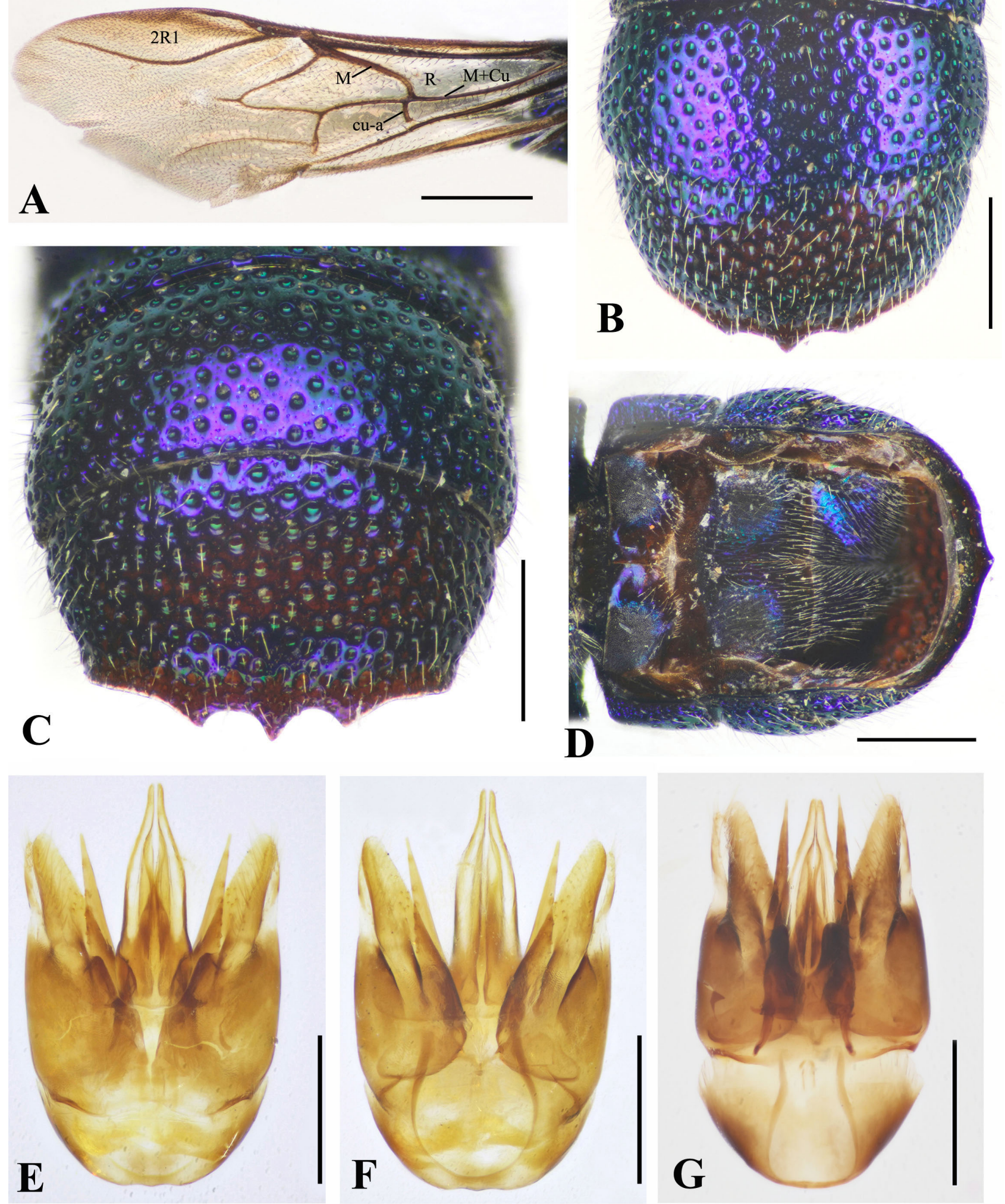

FIGURE 3A-G. Odontochrydium arabicum sp. nov. (A-F. male, holotype; G. male, paratype). A. Fore wing; B. T2-T3, dorsal view; C. T2-T3, detail; D. Metasomal sterna; E, G. Genitalia, dorsal views; F. Genitalia, ventral view. Scales A-D =0.5 $\mathrm{mm}$, except $\mathbf{E}-\mathbf{G}=0.25 \mathrm{~mm}$.

Description (Male holotype, Figs 1-3). Body length $5.2 \mathrm{~mm}$. Forewing length $3.9 \mathrm{~mm}$. OOL $1.75 \times$ AOD; POL $2.5 \times$ AOD; MS $1.0 \times$ AOD; P and F1-F3 equal in length.

Colour (Figs 1A-C, 2A-F, 3A-D). Body overall metallic dark blue, with slight greenish reflection on TFC, 
scapal basin, clypeus, pronotal dorsal face and mesopleuron, with violet reflection on T3; legs metallic blue, with tarsi dark brown; first tarsomeres with slight blue reflection; forewing, except hyaline R cell, slightly infumate, in particular 2R1 cell (Fig. 3A), hind wing hyaline; tegula metallic blue; S1 polish brown, with pair of black spots bounded by bluish reflection; S2 and S3 metallic blue, former polish brown anteriorly, with pair of black spots; scape and pedicel blue, flagellomeres black; mandible bluish on basal half, brown apically. The colour of the specimens while they are alive is bright green with some copper reflections, this colour gradually turns into dark blue after their death.

Pubescence (Figs 1A, B, 3D). Body sparsely setose, setae whitish and short, about $1 \times$ AOD, silvery, erect to suberect, denser and recumbent on S2 and S3.

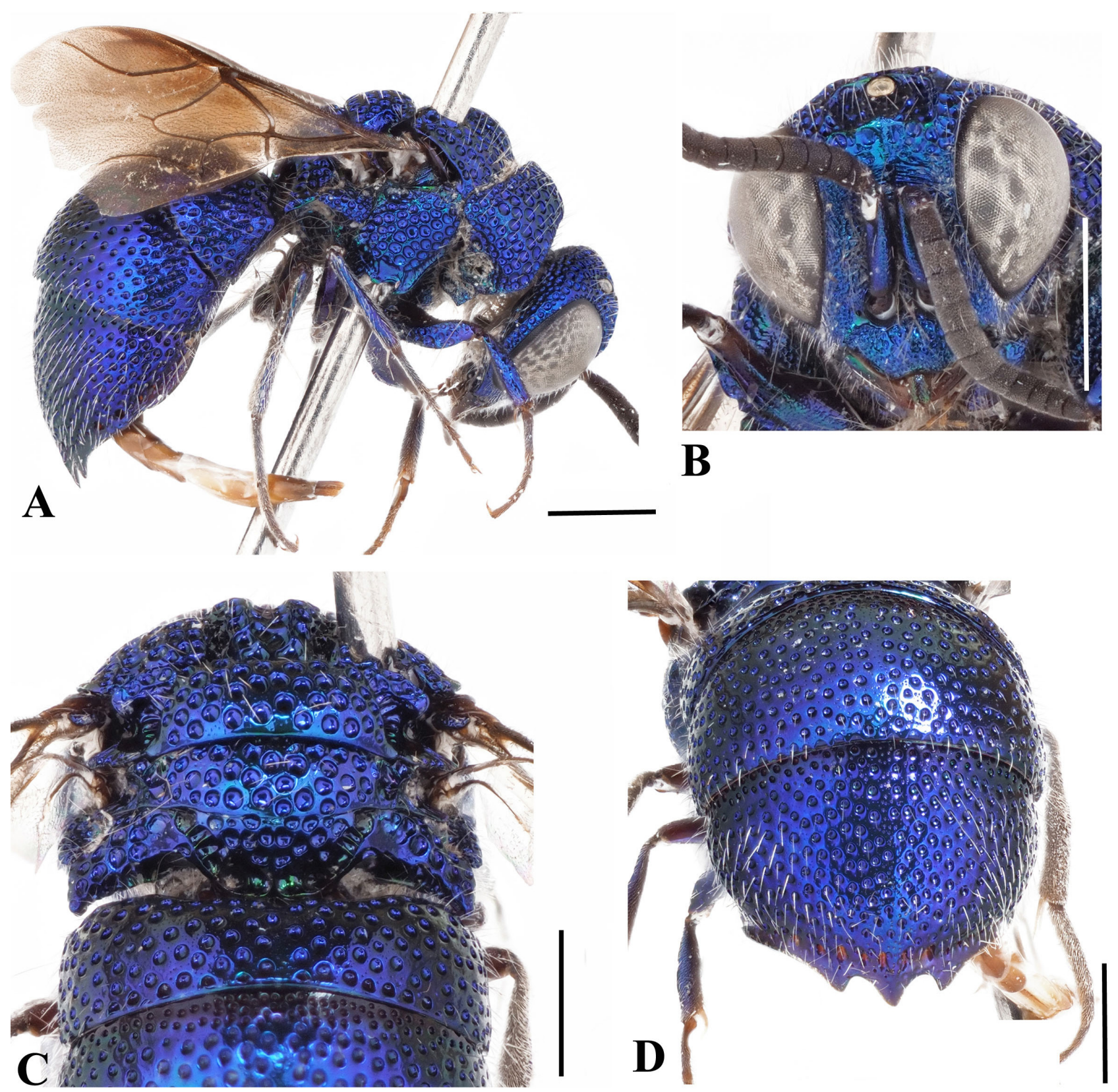

FIGURE 4A-D. Odontochrydium arabicum sp. nov., female, paratype. A. Habitus, lateral view; B. Head, frontal view; C. Mesosoma and T1, detail; D. T2-T3. Scales $=1.0 \mathrm{~mm}$.

Head (Fig. 2A-D, F). Frons with strong TFC, weakly angulate medially, with branches encircling mid-ocellar area, forming kidney-shaped area, less deeply punctate than rest of vertex and almost polished around anterior ocellus; vertex and frons largely deeply punctate-reticulate; scapal basin deep, medially strongly, transversely ridged; laterally with small punctures between ridges and covered with suberect silvery setae, densely punctulate with similar 

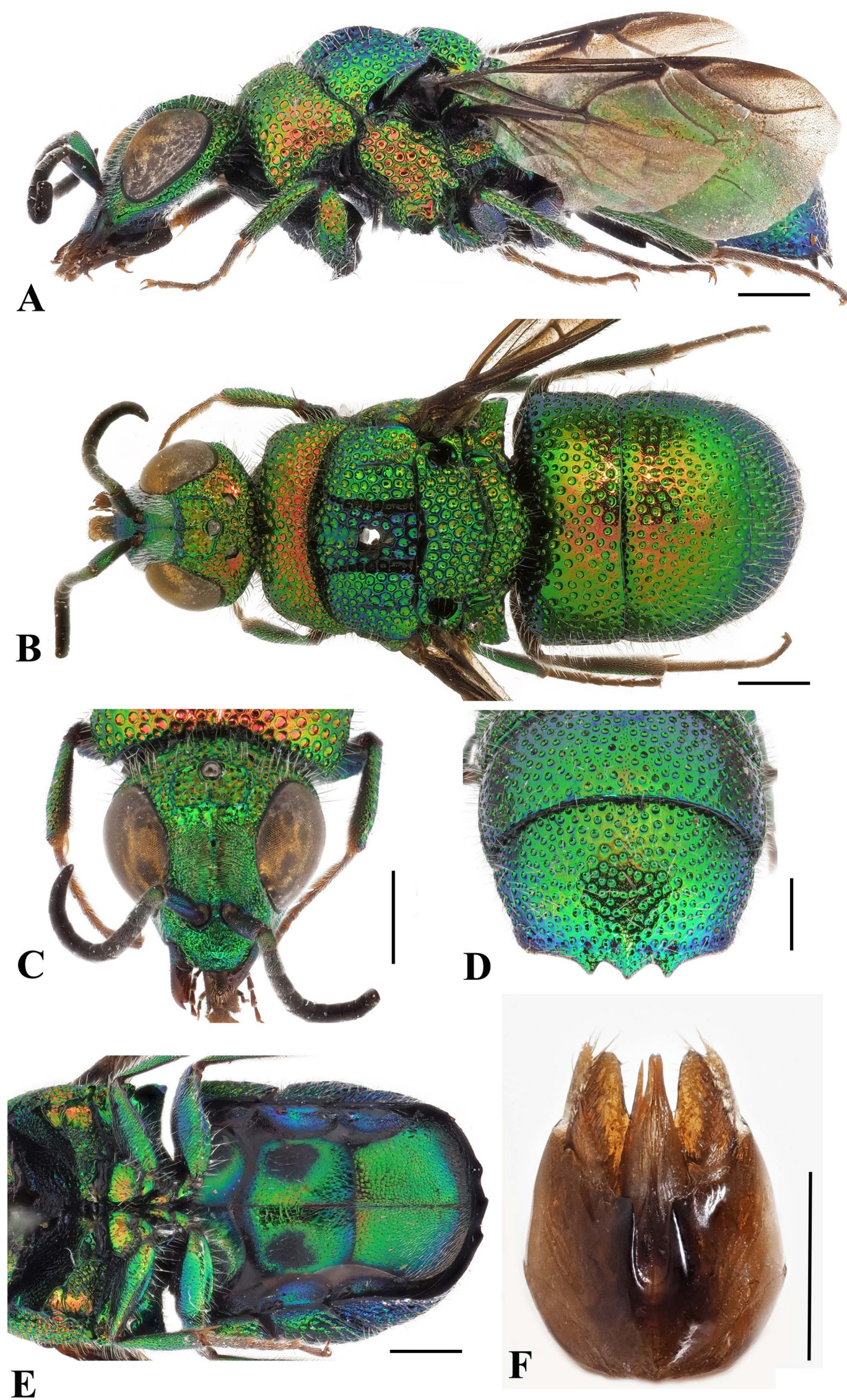

FIGURE 5A-F. Odontochrydium bicristatum Rosa, male, paratype. A. Habitus, lateral view; B. dorsal view; C. Head, frontal view; D. T2-T3; E. Mesosomal sternum (part) and metasomal sterna; F. Genitalia, ventral view. Scales $=0.5 \mathrm{~mm}$. 
setae along inner eye orbit; clypeus densely irregularly punctulate, with tiny dots mixed with small punctures, hardly convex on disc, relatively short, with subantennal distance $1.6 \times \mathrm{AOD}$, with margin straight; antennal sockets close, about $0.4 \times$ AOD apart; malar space finely reticulate-punctulate, about $1.0 \times \mathrm{AOD}$; genal carina strong and complete; anterior ocellus and posterior ocelli lidded; mandible subdistally toothed.

Mesosoma (Figs 1A, 2C-F, 3A). Pronotal shelf with two deep submedial pits, with polished median area; pronotal dorsal face largely punctate-subreticulate, with punctures up to $0.75 \times \mathrm{AOD}$, and with interspaces micropunctate; with strongly incurved anterior margin, and posterior margin slightly incurved; with antero-median groove wide and relatively shallow, impunctate and polished on anterior $2 / 3$, reaching more than $3 / 4$ of pronotal length; pronotal humeral angles acute; mesoscutum foveate-reticulate on median lobe and on greater part of lateral lobes; punctate-subreticulate adjacent to tegula, with punctures up to $0.8 \times \mathrm{AOD}$; median mesoscutal lobe with two stout longitudinal ridges and elongate fovea between ridges; tegula narrowed and partially hide; notauli complete, deeply, irregularly foveate; parapsidal furrows developed only until half mesoscutal length; mesoscutellum and metanotum subreticulate-punctate, the latter evenly rounded; propodeal lateral angle rather narrow, with blunt apex and incurved posterior margin; mesopleuron ventrally nearly smooth and armed with three strong teeth, dorsal teeth subequal; fourth sharp tooth present posteriorly on mesopleuron, before metapleuron. Forewing with distal area of Rs $1 \times$ AOD apart from wing margin; $\mathrm{M}$ meets $\mathrm{M}+\mathrm{Cu}$ before cu-a.

Metasoma (Figs 2D, 3B-D). Exposed tergites sparsely setiferous punctate, interspaces between punctures smooth to finely punctulate; T3 convex and continuous in profile, without pre-pit swelling or post-pit sunken areas; pit row somewhat distinct, pits small, deep; T3 apical margin with three subtriangular teeth, median tooth slightly longer than lateral ones.

Genitalia (Fig. 3E, F). Gonostyle hardly shorter than cuspis of volsella; apex of aedeagus digitate; digitus as long as cuspis.

Female (Fig. 4A-D). Similar to male except body with more violet tint, in particular on bottom of punctures; forewing darker; T3 distinctly acuminate posteriorly, with apico-median tooth distinctly longer than lateral ones.

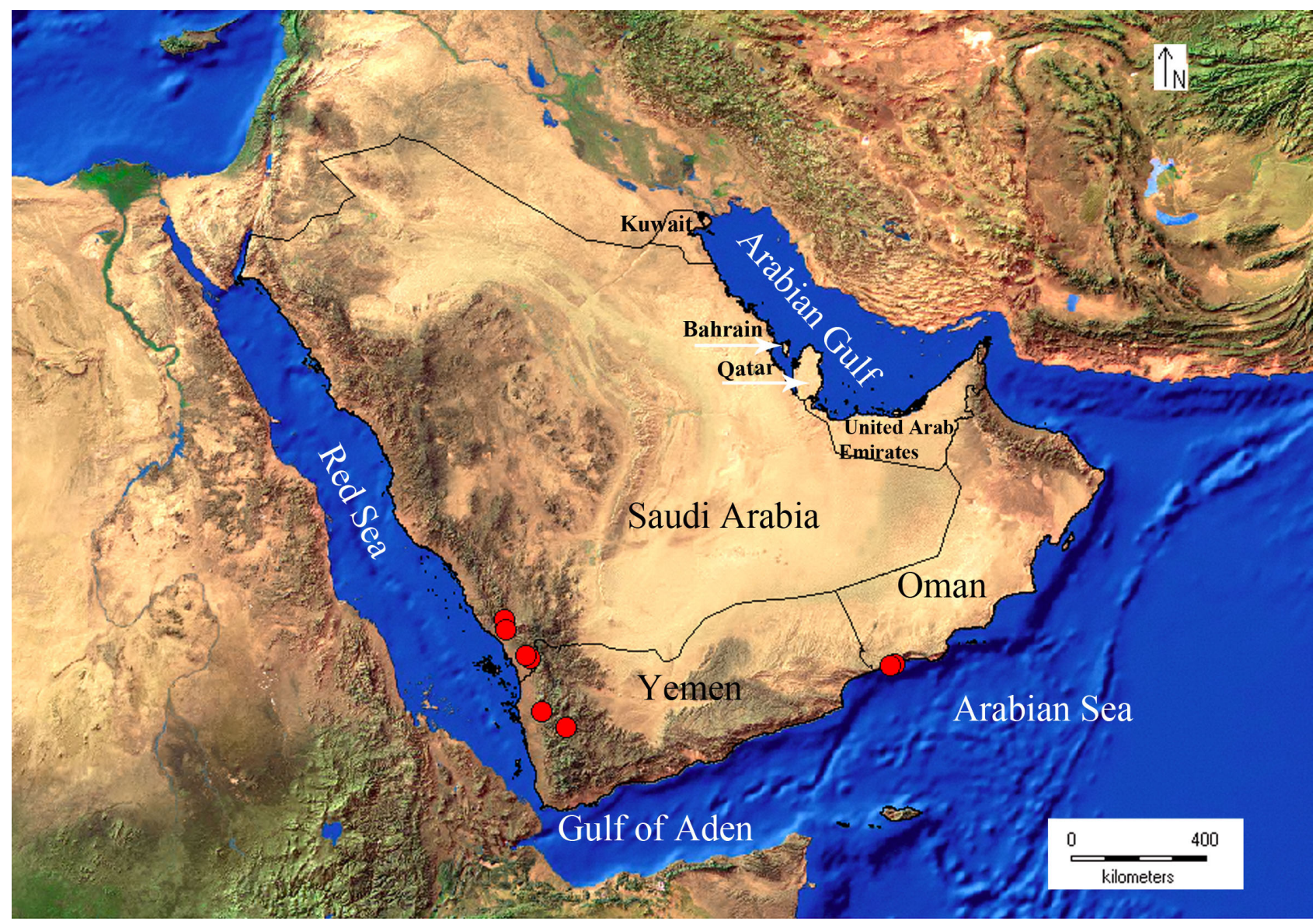

FIGURE 6. Distribution map of Odontochrydium arabicum sp. nov. in the Arabian Peninsula. 
Recognition. The male of Odontochrydium arabicum sp. nov. is similar to the male of the African species $O$. bicristatum (paratype, Fig. 5A-F) by having mesoscutal median area reticulate-foveate, with two stout longitudinal ridges and T1-T3 sparsely largely punctate; it differs from the latter by: body generally metallic dark blue, sometimes with a little violet tint on T3 and on bottom of punctures (Figs 1, 3D), vs. metallic green in O. bicristatum, with a little bluish tint on mesoscutum, sometimes being rosy to golden red on the head, pronotum and metasomal tergites in prepared specimens (Fig. 5A-E), likely golden or red in nature; clypeus short, with subantennal distance $1.6 \times$ AOD (Fig. 2A), vs. longitudinally elongate, with subantennal distance $2.0 \times$ AOD (Fig. 5C); pronotum with large, deep and dense punctures (Fig. 2C), vs. pronotum with sparser and smaller punctures, not distinctly deep (Fig. 5B); mesoscutellum with sparse, large and round punctures, with wide interspaces bearing small dots (Fig. 2E), vs. mesoscutellum with dense, polygonal punctures without interspaces (Fig. 5B); metanotum with similar punctation, with large, round and deep punctures (Fig. 2D, E), vs. metanotum with dense, not particularly deepened polygonal punctures (Fig. 5B); propodeal lateral tooth obtuse apically (Fig. 2D), vs. sharp apically (Fig. 5B); T3 without longitudinal median ridge (Fig. 3C), vs. T3 with micropunctate longitudinal median ridge (Fig. 5D); apico-median tooth of T3 longer than lateral ones (Fig. 3C), vs. hardly longer than lateral teeth (Fig. 5D); S2 with longer and denser pubescence (Fig. 3D), vs. S2 with shorter and sparse setae (Fig. 5E); gonostyle hardly shorter than cuspis of volsella (Fig. 3E, F), vs. longer than cuspis of volsella in O. bicristatum (Fig. 5F).

Remarks. Due to a fracture at the inner side of the genital gonocoxae of the holotype male genitalia (Fig. 3E), where they meet, during the preparation for photographing, we added a figure of a complete genital capsule of a paratype (Fig. 3G) in order to clarify the normal shape of the capsule.

Etymology. The new species name refers to the Arabian Peninsula, where the type specimens were collected.

Distribution. Oman, Saudi Arabia and Yemen.

\section{Discussion}

The present study provides new distributional data for the Chrysididae of the Arabian Peninsula. The close affinities of the new species to the African O. bicristatum support the traditional views of Sclater (1858) and Wallace (1876), who proposed that the northern border of the Afrotropical realm lies along the Tropic of Cancer. Consequently, the part of the Arabian Peninsula, in which our present study is based, falls in the Afrotropical realm (Hölzel 1998). Additional material from the region is needed to assess the real distribution of the new species, which could be also distributed in part of the East African countries close to the Arabian Peninsula, such as Eritrea, Djibouti and Ethiopia.

Furthermore, because of the biodiversity richness of Arabian Peninsula, the largest peninsula on Earth, more chrysidid species are expected to occur. Therefore, future collecting trips and studies are needed to clarify the distribution of this family in this part of the world.

\section{Acknowledgments}

We thank Frederique Bakker (Naturalis, The Netherlands) and Marek Halada (České Budějovice, Czech Republic) for the loan of unidentified material from Oman and Yemen. Sincere gratitude to Celso O. Azevedo (Universidade Federal do Espírito Santo, Departamento de Ciências Biológicas, Vitória, Brazil), Hossein Lotfalizadeh (Department of Plant Protection, East-Azarbaijan Agricultural and Natural Resources Research and Education Center, Tabriz, Iran) and the anonymous reviewer for their critical reviewing of the manuscript which led to its improvement. Sincere appreciation extended to the Deanship of Scientific Research at King Saud University for funding this research group number RGP-1437-009.

\section{References}

Brauns, H. (1928) Beitrag zur Kenntnis afrikanischer Chrysididen. Entomologische Mitteilungen, 17 (6), $383-393$.

Goulet, H. \& Huber, J.T. (1993) Hymenoptera of the world: An identification guide to families. Research Branch Agriculture Canada, Ottawa, 668 pp. [https://www.researchgate.net/publication/259227143]

Harris, R.A. (1979) A glossary of surface sculpturing. California Department of Food \& Agriculture. Occasional Papers in 
Entomology, 28, 1-31. [https://zenodo.org/record/26215\#.X4DTUdAzbIU]

Hölzel, H. (1998) Zoogeographical features of neuroptera of the Arabian Peninsula. Acta Zoologica Fennica, 209, $129-140$.

Kimsey, L.S. \& Bohart, R.M. (1991 [1990]) The Chrysidid Wasps of the World. Oxford University Press, New York, New York, IX $+652 \mathrm{pp}$.

Madl, M. \& Rosa, P. (2012) A catalogue of the Chrysididae (Hymenoptera: Chrysidoidea) of the Ethiopian region excluding Malagasy subregion. Linzer Biologische Beiträge 44 (1), 5-169. [https://zenodo.org/record/5327908\#.Yf-6FepBzDc]

Mocsáry, A. (1914) Chrysididae plerumque exoticae novae. Annales Historico-Naturales Musei Nationalis Hungarici, 12 (1), $1-72$.

Rosa, P. (2018) Review of Odontochrydium Brauns (Hymenoptera, Chrysididae) with description of two species from the Palaearctic and Oriental regions. Zootaxa, 4450 (4), 445-457.

https://doi.org/10.11646/zootaxa.4450.4.3

Rosa, P., Gadallah, N.S. \& Brothers, D.J. (2020) Biodiversity of the aculeate wasps (Hymenoptera: Aculeata) of the Arabian Peninsula: Chrysidoidea, Chrysididae. Zootaxa, 4754 (1), 92-101.

https://doi.org/10.11646/zootaxa.4754.1.10

Sclater, P.L. (1858) On the general geographic distribution of the members of the class Aves. Proceedings of the Linnean Society of London, Zoology, 2, 130-145. https://doi.org/10.1111/j.1096-3642.1858.tb02549.x

Wallace, A.R. (1876) The geographical distribution of animals, with a study the relations of living and extinct faunas as elucidating the past changes of the Earth's surface. Macmillan \& Co., London, 503 pp.

https://doi.org/10.5962/bhl.title.30514 